\title{
From Qitāl to Difā': The Meaning and Behavior of Jihad according to Jihadists in Semarang City
}

\author{
Anthin Lathifah \\ Universitas Islam Negeri Walisongo, Semarang \\ e-mail: anthin_lathifah@walisongo@ac.id
}

\begin{abstract}
This paper describes the meaning and act of religion-based jihad according to some jihadists in Semarang city. Insisting that the real meaning of jihad is qitäl (war, to fight) as said by the verse "Lă hukma illa li-lläh" and hadith "faqtulū haythu wajadtumūhum" they, however, still propose another jihad called difä' (defensive, to survive) for people who cannot meet the requirement of qitāl. The different act of jihad emerges because of its different factors behind such as social, economy, politics, psychology and others. The shift from qitāl to difä takes place by the process of humanizing the jihadists using: 1) personal approach by their morally closest men; 2) basic need approach such as economy, existency and peace; 3 ) religious approach by understanding that what they do is to fully adhere to Islam (kaffah); 4) emotional approach by caring and giving them empathy; 5) social approach by building solidarity to help their comrades.
\end{abstract}

Artikel ini mendeskripsikan makna dan perilaku jihad dari para pelaku jihad berbasis agama di Kota Semarang. Makna jihad yang sebenarnya bagi mereka adalah qitāl sebagaimana ayat "Lā hukma illa li-llāh" dan hadis "faqtulū haythu wajadtumūhum", namun jihad difä̆ dapat dilakukan bagi yang tidak memenuhi syaratjihad qitāl. Perbedaan perilaku jihad terjadi karena perbedaan faktor yang melingkupinya, yakni faktor sosial, ekonomi, politik, psikologi dan lainnya. Perubahan perilaku jihad (qitāl) menjadi difă' terjadi karena proses memanusiakan manusia yang dilakukan dengan: 1) pendekatan personil yang dilakukan oleh orang yang dekat secara moril; 2) pendekatan berbasis kebutuhan primer mereka baik ekonomi, eksistensi ataupun rasa aman; 3) pendekatan agama dilakukan dengan memahami apa yang mereka lakukan adalah dalam rangka melakukan Islam secara kaffah; 4) pendekatan emosional dengan memberi perhatian atau empati; 5) pendekatan sosial dengan membangun solidaritas untuk membantu teman-teman seperjuangannya.

Keywords: jihadists; qitāl; difă'; behavior; meaning 


\section{Introduction}

Someone's understanding of jihad seems to influences his action categorized as jihād fi sabïlillāh ${ }^{1}$ (on Allah's cause). For a believer, jihād fi sabīlillāh is normatively considered as a primary deed (afḍal al-'a'māl), so that the only reward is the paradise ${ }^{2}$ when he/she dies. For some, however, the most primary jihad is understood by bearing arms (qitāl) to embattle those considered as infidels or anyone who defends those infidels, an act that had been performed by Imam Samudera and his comrades who famously did their jihad by bombing and thus killing many people in Bali, most of them are foreigners, called Bali I and Bali II incident. In a similar tone, suicide bombings carried out in police mosque in Cirebon and Thamrin, Jakarta recently is another example of this kind of jihad.

Their religious act or behavior which they interpret it as jihad has very different meaning from those who disagree with, calling that qitāl jihad actions are a part of religion-based terrorism or radicalism..$^{3}$ Misrawi divides those terrorism act into three forms. ${ }^{4}$ First is individual terrorism which is carried out by an individual such as church bombing in Solo. Second is collective

${ }^{1}$ Among qur'anic verses that explain jihad are QS. al-Baqarah: 19; QS. al-Tawbah: 20; QS. al'Ankabūt: 6, 69; QS. al-Hujurāt: 15. In a hadīth, Ibnu Mas'ud narrated: I asked Allah's Messenger, "O Allah's Messenger! What is the best deed?" He replied, "To offer the prayers at their early stated fixed times." I asked, "What is next in goodness?" He replied, "To be good and dutiful to your parents." I further asked, what is next in goodness?" He replied, "To participate in jihad in Allah's cause."I did not ask Allah's Messenger anymore and if I had asked him more, he would have told me more. See Abū Abdullāh Muhammad bin Ismāîl bin Ibrāhim bin al-Mughīrah bin Barzdabah al-Bukhārī, Șahịh alBukhārī (Beirut: Dār al-Fikr, 1401/1981), 200.

${ }^{2}$ Abu Huraira narrated: I heard Allah's Messenger saying, "The example of a Mujahid in Allah's Cause -and Allah knows better who really strives in His Cause- is like a person who fasts and prays continuously. Allah guarantees that He will admit the Mujahid in His Cause into Paradise if he is killed, otherwise He will return him to his home safely with rewards and war booty."See: al-Bukhārī, 201.

3Etimologically, terorism originates from the word "terror", meaning one of a group's effort to create fear, horror and cruelty. One who uses violence to create fear or horror is called terrorist. Conclusively, terrorism is terminologically the use of violence to create fear to reach its goal. See: Arrager Team of Kamus Besar Bahasa Indonesia, Kamus Besar Bahasa Indonesia, 3rd ed. (Jakarta: Balai Pustaka, 2005), 1185; W.J.S. Poerwadarminta, Kamus Umum Bahasa Indonesia, 3rd ed. (Jakarta: Balai Pustaka, 2006), 1263.

4Zuhairi Miswari, "Islam dan Terorisme," Islam Lib, 2002, retrieved on 23 September 2012. http://islamlib.com/politik/radikalisme/islam-dan-terorisme/; see: Muzayyin Ahyar, "Membaca Gerakan Islam Radikal dan Deradikalisasi Gerakan Islam," Walisongo: Jurnal Penelitian Sosial Keagamaan 23, no. 1 (June 15, 2015): 1-26, https://doi.org/10.21580/WS.23.1.220. 
terrorism which is institutionalized by a neat network where the terrorists execute their job in such a well-planned action like al-Qaeda did, targeting symbols of power and economic centers. The third is state terrorism, a new term to call a country which steadily oppresses its people.

It is important to comprehend one's understanding on jihad since it will determine how one should behave in the name of jihad, as committed by jihadists who live in Semarang city and believe that what they did is a jihad. This paper will describe how they understand the concept of jihad, what has become their basic action to perform jihad and why their act shifts from qitāl to difä'jihād.

\section{The Religious Meaning and Behavior}

As one of the manifestations of religiosity, one's behavior or act is influenced by one's understanding of the religion itself. Besides being found on religious belief, religious phenomena also appear in the practice of rituals, Durkheim explains. Examining some basic problems of religion, he divides religious phenomena into three: 1) group of life which becomes the primary source or cause of religion; 2) ideas and practices of religion which refers to symbol or being symbolized by a social group; 3) distance between the sacred and profane which mainly occurs and creates important impact in social life. 5

According to Weber, once a religious movement connects with social behavior, the aspect of worldview will employ an important position with regard to the subjective meaning of a person. It implies that more than a coincidence, everyone's action draws full meaning of his/her belief. Weber even situates worldview as a unique belief system, since religion poses new religious orientation involving a system of theology and comprehensively ethic teaching. ${ }^{6}$

According to Hanafi, the essence of religious existence could tenaciously influence religious believers since Islam, as a religion, not only does operate on its ideology but also orchestrates its follower's behavior and even becomes

\footnotetext{
${ }^{5}$ Anthony Giddens, Kapitalis dan Teori Sosial Modern (Jakarta: UI Press, 1986).

${ }^{6}$ Ralph Schroeder, Max Weber tentang Hegemoni Sistem Kepercayaan, translated by Ratna Noviani (Yogyakarta: Kanisius, 2002), 83.
} 
an ideal type of their minds and life choices. ${ }^{7}$ In addition, Arkoun believes that understanding Islam is a conscious activity that includes historical, social and political context, which will be fruitful to examine the development of Islamic fundamentalism. According to him, social and political allurement has created an ideological form in the human mind. ${ }^{8}$

Drawing on the above theory and context, the implementation of one's religious activity on a sacred teaching such as jihad seems to highly depend on the subjective meaning. It is then considered to be a worldview which plays as a root of an ideally religious act performed by a Muslim.

\section{The Concept of Jihad}

Etymologically derived from words "jahada yajhadu jihādan", jihad means "the earnest effort", ${ }^{9}$ or "struggle". 10 The word jihād is a form of mașdar (noun) "jihādan wa mujāhidatan" from jahada, so that jihād fi sabīlillāh means a struggle on Allah's cause. ${ }^{11}$

Terminologically, Hanafiyyah school argues that jihad meaning is exerting every opportunity and power to hold altogether on Allah's cause, exercising life, wealth, words and others (bi 'l-nafs wa 'l-māl wa 'l-lisān aw ghayri dhālik). On another side, Shafi'iyyah school interprets jihad as an exemplary action performed and tracked from the history of Muhammad. Malikiyyah school interprets it as a Muslim battle against the infidels who are not bound to enforce or deliver God's teaching. Meanwhile, Hanabilah school insists that jihad is fighting the infidels, in particular, i.e non-Muslims who disobey, become pirates and others. ${ }^{12}$

\footnotetext{
7Hassan Hanafi, Islam in the Modern World: Tradition, Revolution and Culture, Vol 2 (Cairo: Dar Kebaa Bookshop, 2000), 410.

8Mohammed Arkoun and Robert D. Lee, Rethinking Islam: Common Questions, Uncommon Answers, ed. Robert D. Lee (Michigan: Westview Press, 1994).

${ }^{9}$ Ahmad Warson, Kamus Arab-Indonesia Al-Munawir (Surabaya: Pustaka Progressif, 1997), 217.

10Atabik Ali dan Ahmad Zuhdi Muhdlor, Kamus Kontemporer Arab Indonesia (Yogyakarta: Multi Karya Grafika, 1999), 702.

11Warson, Kamus Arab-Indonesia Al-Munawir, 217.

12Ibn Abidin, Radd al-Mukhtār, juz 6 (Beirut: Dār al-Ma’ārif, 1424 H/2003 M), 193-221.
} 
Qardhawi insists that jihad is a comprehensive dimension as a part of fiqh mu'âmalah. ${ }^{13}$ Jihad in the sense of war and military preparations are included in the context of the community and the state since the purpose of jihad is to maintain the spiritual and material existence of a society, as well as maintain the religious people and their life from enemy attack. Thus jihad is part of fiqh jamä'ah, while the fiqh of jihad turned into fiqh fardi when the community no longer exists.

According to Majid Khadduri,14 jihad means an earnest effort on Allah's cause, to spread the faith and the words of God to the world. Jihad is an individual teaching of achieving the salvation because jihad is the guidance of Allah leading man to go straight to heaven. Jihad, therefore, does not necessarily mean waging a war or battle, for following Allah's cause can be achieved either by peaceful or violent conduct. Jihad is also regarded as a religious propaganda conducted through persuasive action or sword (war). In the early revelation in Mecca, the substantial revelation advocated many persuasive actions, as Prophet Muhammad delivered his prophetic by reminding people who worshipped idols to worship God. This is portrayed in QS. al-Ankabūt: 6 "He tried earnestly (jahada), trying with all of his heart". This verse draws jihad as a salvation effort, trying to Islamize the hearts of other people. Meanwhile, during the revelation period in Medina, jihad is often appreciated differently, namely the anonymity of jihad with qitäl.

The Islamic law scholars distinguish four ways to meet the call of jihad, namely: with his heart, tongue, hand, and sword. The first way is in line with the command against the devil and trying to avoid the blandishments of Satan, regarded as the greatest jihad by Prophet Muhammad. The second way is done for the enforcement of the truth. A third way is to correct mistakes. The fourth way is equivalent to the meaning of the war and focused on the war against the

\footnotetext{
${ }^{13}$ Figh muamalah is an Islamic law related to human life either indivual such as halal-haram (allowed and forbidden), family such as marriage, divorce, inheritance and trusteeship, society such as trade and civil activity, state such as responsibility and criteria of a leader as well as rights and obligation of people administered by constitution, community such unity, rules and sharia law or relation with another country in peace or war situation. See: Yusuf Qardhawi, Fiqh Jihad: Sebuah Karya Monumental Terlengkap tentang Jihad Menurut Al-Qur'an (Bandung: Mizan Publika, 2010), 10.

${ }^{14}$ Majid Khadduri, War \& Peace in the Law of Islam: Perang dan Damai \& Hukum Islam, translated by Kuswanto (Yogyakarta: Tarawang Press, 2002), 46-7.
} 
infidels and enemies of Islam. It is understood that "people are obliged to sacrifice wealth and their lives" (QS. al-Saff: 11) through the war. ${ }^{15}$

Furthermore, Khadduri describes several types of jihad experienced during the time of the Prophet and the companions. In historical perspective, the jihad of war was ever undertaken to fight against the polytheists, apostasy, baghy, dissidents, robbers and against the People of the Books (Ahl al-Kitāb) and ribat. However, the war is actually waged in the context of protecting the politics of dār al-Islām (Islamic state).16

Similarly, Rohimin explains that jihad is one of the teachings that are central, unique and very fundamental. Equating jihad with war is reductively one of the mistakes since war is just a temporary manifestation of the understanding and teaching of jihad and jihad itself is a continuous struggle for life. The substantial doctrine of jihad is seen as worldly and heavenly religious teaching. For instance, the affirmation of the Qur'an for Muslims to do jihad has existed since the Mecca period. A suggested jihad in the sense is da'wa, selfcontrol and patiently to face of persecution waged by the Pagans. The substance of the doctrine of jihad is therefore described by focusing on the aspects of worship and vertical nature. While in the Medina period, jihad is more focused on understanding the war, the resistance of the Muslims against the threat and enemies attack. ${ }^{17}$

Rohimin further explains that the exposure of jihad in the Qur'an does not stand alone but relates to other teachings, especially faith, hijrah (emigration) and patience. This fact indicates that the doctrine of jihad is important teachings to note. The purpose of jihad according to the Qur'an is not limited to political and military objectives, it includes more important religious purposes such as; extending religious teachings, testing the patience, preventing the enemy threat, preventing injustice and maintaining an agreed treaty. As such, the important functions of jihad teachings appear in the aspect of worship, da'wa, politics, military as well as religious and spiritual aspects. Thus, the objects of jihad in the Qur'an are infidels, hypocrites, idolaters, lust and

15Khadduri, War \& Peace, 47.

16See: Khadduri, War \& Peace, 61-7.

17Rohimin, Jihad: Makna dan Hikmah (Jakarta: Erlangga, 2007), viii.

6 || Vol 28, No. 1, April 2018

AL-AHKAM 
insurgents or al-bughat. However, the most important is that whatever the form of jihad is imposed, it must be within the limits of jihäd fi sabilillāh, for the sake of elevating the religion of God. Meanwhile, the indicated forms of jihad in the Qur'an are jihad with the Qur'an (al-jihād bi 'l-Qur'ān), with wealth (al-jihād bi 'l-māl), and with life (al-jihād bi 'l-nafs).18

Bonner argues that jihad in Islam relates to the war, although in the perspective of the history of Islam, both in doctrine or practice, it is never in one form, changes depending on the context. Therefore, the meaning of jihad does not only mean holy war, although jihad literally means "struggle". But when the word jihad is followed by the phrase fi sabilillāh (on Allah's cause), it can be in the form of ribat, ghazw, ghazwa, ghazā, qitāl, and harb. ${ }^{19}$

Hence, according to Bonner, it is wrong to equate the meaning of jihad to terrorists or peace. According to the historical perspective of Islam, jihad is complex doctrines and practices those changes over time and continues to grow. He understands that the message of the Qur'an about the battle and jihad is inseparable from the requirements of generosity and concern for the poor. Therefore, jihad often becomes a constructive and creative force, a key to building a new Islamic society and state. Actually, according to Bonner, jihad has been set in the context of relations between Muslims and non-Muslims whether in peace or in a war situation. However, Bonner sees "jihad" in the present and in some ways follow the tradition of "classical" jihad, regardless of the context.

Rumadi explains that when interpreted as holy war, jihad contradicts its terms (contradictio in terminus). War indicates violence, murder and extermination, while the sanctity of religion was necessary for gentleness, compassion, and mutual respect. Thus, the sanctity attached to the war is a theological claim used to justify a particular religious group. This can be seen in the Crusades War that occurred between Muslims and Christians, when Muslim consider their fight against Christians as a jihad in the name of God, as Christians also have similar claims. ${ }^{20}$

\footnotetext{
18Rohimin, Jihad, 10.

${ }_{19}^{19}$ Michael Bonner, Jihad in Islamic History: Doctrine and Practice (UK: Princeton University Press, 2008).

20Rumadi, Renungan Santri; Dari Jihad Hingga Kritik Wacana Agama (Jakarta: Erlangga, 2006), 83.
} 
The concept of jihad according to Rahman is interpreted as a total struggle both with wealth and life in order to achieve happiness in the afterlife as described in QS. al-Tawbah: 41. Therefore, jihad is a must. ${ }^{21}$ In fact, according to Mirza Ghulam Ahmad, as Burhanuddin examines, jihad is not qitāl. Ghulam Ahmad said that "it is not allowed to attack either enemies or infidels who do not interfere in matters of faith and do not prohibit the development of religion".22

In the recent context of Indonesia, according to Munir Mulkhan, the concept of jihad is not to bear the arms up, since the fight against corruption is a culture of jihad of bi 'l-nafs which is greater than jihad in the sense of qitāl. This happens because the biggest enemy of Islam movement emerges from within, of its own adherents who do not care about the quality of people's lives under the corruptive and unfair practices of the government. In fact, according to Mulkhan, jihad against corruption is as important as the fight against secularism, hence corruption needs to be placed as the greatest enemy of religious movements of this century. ${ }^{23}$

Masdar Hilmy also states that the fight against corruption is included into jihād fi sabilillāh, hence, when there is a saying ish karīman aw mut shahïdan, it insists that the fight against corruption is a noble deed and when someone dies during that fight, it would be honored as a martyr. ${ }^{24}$

Furthermore, Gilles Kepel ${ }^{25}$ explains that from the aspect of movement, the jihad of radical Muslim is a political perspective. He explains that in the 1970s and 1980s, radical Islam has experienced its victory as a social and political force throughout the Middle East. Additionally, since the 1990s, a local movement of radical Islam changed and shifted away from the domestic to the international scene as the incident of 9/11.

\footnotetext{
21Fazlur Rahman, Tema Pokok al-Qur'an (Bandung: Pustaka, 1983), 93-4.

22See: Asep Burhanudin, Ghulam Ahmad: Jihad tanpa Kekerasan (Yogyakarta: LKiS, 2005$), 47$. Examining the concept of jihad by Ghulam Ahmad in India, Burhanuddin suggests that Ghulam urges weak Muslims not to fight against British government since it will make them, the Muslims, more suffered.

${ }^{23} \mathrm{Abdul}$ Munir Mulkhan, Manusia al-Qur'an: Jalan Ketiga Religiousitas di Indonesia (Yogyakarta: Kanisius, 2007), 214.

24Masdar Hilmy, Islam Profetik: Substansi Nilai-nilai Agama dalam Ruang Publik (Yogyakarta: Kanisius, 2008), 133.

25Gilles Kepel, Jihad: The Trail of Political Islam (London, UK: I.B.Tauris, 2002), vi-vii.
} 
Samuel M. Katz explains the long history of jihad as a holy war. From the historical data, in the early 11th century occurred the Crusade war, continued during the Ottoman Empire against the European countries, to the seizure of Jerusalem by Islam and Israel. Then the movement of the Muslim Brotherhood of Hasan al-Banna emerged in 1928 in Egypt until the late of the 1960s when his successors fought to replace the secular Egyptian government with Islamic State. After that, the jihad of Hizbullah emerged in Afghanistan in 1989 when global jihad movement emerged for the unity of the Islamic movement in the world led by Al-Qaeda until the movement of the fundamentalists Taliban in Afghanistan was established in 1996 to 2001 backed by Al-Qaeda and Osama bin Laden. ${ }^{26}$

Similarly, in perspective of the jihadist movement, Ismail Hasani and Bonar Tigor Naipospos ${ }^{27}$ explain that the origin of terrorists in Central Java which emerges from the radical movement. Both conclude that one factor led to the emergence of terrorism closely linked to radicalism and intolerance taught by Islamic hardliners is the starting point of terrorism. There are similarities between the intolerant radical groups and terrorist groups, among which support the application of Islamic law, fight against what they perceive as immoral, and the establishment of an Islamic state. For example, the case of Joko Jihad confirms that an originally intolerant individual transforms himself to be a terrorist group.

Ronald Alan Lukens-Bull reveals differently in his "Peaceful Jihad." He writes that jihad is not only in the sense of violence as understood by the West, but there exists also the perspective of peaceful jihad undertaken by Islamic boarding schools (pondok pesantren) in Java, such as Pesantren Tebuireng, Pesantren An-Nur II, Pondok Mahasiswa Firdaus, Pesantren Mahasiswa AlHikam and Pesantren Kampus Ainul Yaqin. ${ }^{28}$

${ }^{26}$ Samuel M. Katz, Jihad: Islamic Fundamentalist Terrorism (Minneapolis: Lerner Publications Company, 2004).

${ }^{27}$ Ismail Hasani and Bonar Tigor Naipospos, Dari Radikalisme Menuju Terorisme (Jakarta: Pustaka Masyarakat Setara, 2012).

28See: Ronald Alan Lukens-Bull,Jihad Ala Pesantren di Mata Antropolog Amerika, ed. Abdurahman Ma'ud (Yogyakarta: Gama Media, 2004); Sulasman Sulasman, "Peaceful Jihād dan Pendidikan Deradikalisasi Agama," Walisongo: Jurnal Penelitian Sosial Keagamaan 23, no. 1 (2015): 151-76, 
Thus, it appears that the meaning of jihad theoretically changes according to socio-historical context, so that the ideal meaning of jihad cannot, to be said, be the formulation of a physical battle or even violence.

\section{Between Qitāl dan Difä'}

The following description is the result of a study related to one's understanding of jihad in the name of religion and reasons to how its results are implemented within behaviors which they call it a jihad. In addition, it also examines why they change their behavior of jihad from qitāl to difä'.

\section{First case: Yusuf ${ }^{29}$}

Becoming a war veteran and member of the Moro Islamic Liberation Front (MILF) based in Mindanao, Philippines, Yusuf admitted that he actually departed from a family-based NU (Nahdlatul Ulama), even his mother became a member of Muslimat NU (women organization of NU) Tebuireng, Jombang.

The background that prompted Yusuf to conduct "jihad of war" started from his meeting with Islamic hard-liner thoughts during his age at high school (SMAN 2 Jombang) around 1994. At that time the world was heavily affected by the Gulf crisis, Iran, Iraq, and Bosnia. According to him, many discussions were often held at the Sospol Mosque related to the Gulf War. Eventually joining the discussion, he asked many questions to the community such as Mr. Salim who has VCD of wars in Bosnia. Realizing that Yusuf has a very great desire to watch, eventually dr. Ifan invited him to the house of Mr. Salim to watch. After watching, Yusuf admitted that he watched a lot of victims of the Muslims, such a western Muslim who was tortured by Caucasians and many more terrible events in Bosnia. In one discussion, Mr. Salim gave advice that "we must be equal between matters of religion and nonreligion, between this world and hereafter."

At that time, Yusuf thought that there was a sense that did not fit between the desire and his ability to deeply understand his religion. He wondered

https://doi.org/10.21580/WS.23.1.228; Thohir Yuli Kusmanto, Moh. Fauzi, and M. Mukhsin Jamil, "Dialektika Radikalisme dan anti Radikalisme di Pesantren," Walisongo: Jurnal Penelitian Sosial Keagamaan 23, no. 1 (2015): 27-50, https://doi.org/10.21580/WS.23.1.221.

29Yusuf, interview, June 12, 2012. 
himself, "how can I possibly understand the religion when I only come from a public school, not a religious school?"He also thought that how he has religious provisions to stabilize his life when he realized at that time many Muslims were oppressed. His thoughts were sparked from reading a variety of media, including books that he got at the library and the Jombang Mosque, as well as Sabili and Hidayatullah magazines. Having no sufficient basis of religious knowledge, he eventually intended to "nyantri" (study and live) at Pesantren Ngabar Ponorogo in which he massively joined the discussion and study at its mosque and campus called "Riyadul Mujahidin". Yusuf ever discussed with friends about Kahar Mudzakar who has been marginalized because of political affairs. According to him, the view of most people on Kahar Mudzakar was wrong. Kahar Mudzakar was a hero of Islam because he dared to fight to elevate Islam through the motions of DI-TII (Darul Islam/Islamic State and Tentara Islam Indonesia/Islamic Army of Indonesia). About a year, however, Yusuf felt that his campus failed to meet religious aspiration he wanted.

Ngabar's period for around one year did not satisfy him on generating an understanding of jihad. Yusuf then decided to try business by becoming batik distributor of Danar Hadi in Jombang. During his round trips to build his business, he bought a lot of books from Solo such as Abdullah Azzam's Tarbiyah al-jihād (10 volumes, translation), Zilāl al-Țūr, Fiqh Harakah, Sabili and Hidayatullah magazines, as well as various works of Hasan al-Banna. In addition, from the books he read, there were also works of Abu Bakar Ba'asyir containing a plea against Soeharto. Yusuf also questioned "why was there a sole basis? and why was Jakarta Charter deleted?" He then concluded that all happened because of Soekarno.

For Yusuf, the most influential insights have come from the Translation of Qur'an published by the Ministry of Religious Affairs. When juxtaposed with the Abdullah Azam's thoughts of Jihad in Afghanistan, both had the same meaning and significance, particularly in the verse that says "faqtulu haythu wajadtumūhum."

The situation which increasingly madeYusuf attracted by jihad was when the crisis occurred in Indonesia, especially Ambon and Poso in 1998, where there was a genocide of Muslims in 13 villages and their bodies were drowned at the Lake of Poso. Yusuf also began to collect posters of Muslim warfighters 
like Osama bin Laden and kids who bear arms. By doing that, he admitted that he actually idolized every struggle to defend Islam, not the people of those posters. At that time, however, jihad just stayed only in Yusuf's mind.

Running his business, Yusuf still felt unsatisfied and lacked understanding and interpreting jihad in Islam. Deciding to join Pesantren al-Mukmin Ngruki Sukoharjo, some his friends instead suggested him to go to Pesantren Al-Islam, Lamongan, because Ngruki had been experiencing conflict, splitting into two groups. Eventually, he went to Al-Islam, Lamongan, a pesantren which he claimed: "finally affiliated with Muhammadiyah after receiving massive pressure from the government."One day when there was a Tabligh Akbar at the pesantren, a speaker declared that "we must tarji' li 'l-jihād". Shocked and touched, Yusuf asked his friend about who the speaker is, thinking that his speech is the same as Abdullah Azam's fatwa. His friend answered that the speaker was Ali Ghufron a.k.a Mukhlas from Malaysia, later known as one of the Bali bombers.

Spending some time in Pesantren Al-Islam, Yusuf then returned to Jombang and his batik business. However, when Yusuf knew that a lot of friends from Surabaya and Malang participated in Laskar Jihad in Ambon, finally he went to Pesantren Al-Islam, met Mahmudi and registered himself to Surabaya to go to Poso. A few days later, he bought the ticket and went to go there. Yusuf explained that he did not inform his families where he was going, just said he would seek to work outside Java.

Actually, according to Yusuf, the primary reason he wanted to wage jihad was when he watched VCD displaying slaughter in Poso, started by an assault to Islamic boarding school as well as the existence of Tibo and Da Silva. It made Yusuf convinced that the persecution against Muslims happened not only in Afghanistan but also in Poso. For that reason, he believed that jihad should not be necessarily delivered far away to Afghanistan.

Yusuf believed the truth of the hadith "al-mu'minu al-qawiyyu ahabbu 'inda Allāh", as well as the hadith "... alā inna al-quwwata al-ramyu ...". According to Yusuf, the strong believers are they who have the power and love of God, able to protect themselves and others and have the ability to throw darts. Throwing arrow by Yusuf is interpreted as bearing up arms, firing and so forth. For him, 
as long as Muslims are persecuted or intimidated, it should be responded with the equal retaliation ("bi mitsli").

After some time in Poso, a senior jihadist, whom he and many jihadists in Poso respected this senior most, offered him to develop his ability based on his potential in another place. Yusuf followed the advice given by the elders to go to Balikpapan. It turned out that the trip was not only to Balikpapan but also to Toli-Toli and Malaysia. Staying for a while in Malaysia, Yusuf was then asked to board the ship that turned toward the Philippines. There, Yusuf learned guns alike, and become a mujāhid in Moro against persecution and injustice committed by Joseph Estrada against Moro Muslims.

In 2002, or the time of the Bali Bombing II, Yusuf returned to Indonesia after getting permission from his Moro's commander. He claimed not to know both Imam Samudra or Amrozi, the Bali Bombers II, although he spent much time in Moro. After safely arriving in Indonesia and living with his family back, he tried to hide his life history by stating that he had failed and robbed abroad, he only had a balance of IDR 500,000 left on his BII account.

During his difficulties to make money, he was again advised by his senior to join the jihad and meet Mustofa who lived in Kudus. Mustofa then donated him money around IDR 15,000,000. Yusuf used that money to rent a house to live in Semarang and started his business by selling bags, leather jackets, slippers, sarongs, and others.

During the first three months (March-June 2003), the income of his business increased and Mustofa then invited him as a distributor. In July 2003, Mustofa set often to go with his driver, distributing their goods anywhere. However, an unexpected event occurred when the police convicted Yusuf after arresting Mustofa for allegedly supplying ammunition to the terrorists in Indonesia, which was occurred before the bombing at JW Marriot Hotel (Marriot Bombing I). Yusuf was then jailed for allegedly "hiding Mustofa" for a 10-year sentence, while Mustafa was sentenced to 7 years. Prior to the incident, in the fact, Yusuf was suspicious of the goods brought by Mustofa when Mustofaspecifically put large suitcases upstairs. After being raided, Yusuf knew that those suitcases contained explosives material.

Yusuf was finally jailed in Kedung Pane Penitentiary because he lived in Semarang. While imprisoned, he sometimes talked about a lot of things with a 
former officer in the prison. In this prison also, Noor Huda Ismail, known as chairman of Yayasan Prasasti Perdamaian (Peace Inscription Foundation) visited him. When Huda asked about his situation, Yusuf replied, "nothing special." It was the first meeting with Noor Huda and nothing conversation but saying hello as well as asking about the conditions in the prison. Besides Huda, Abu Bakar Ba'asyir also visited Yusuf twice. After being moved to Nusakambangan Penitentiary, Yusuf was shortly released in 2009, because he had a good attitude and been respected by many in the prison.

Yusuf explained that after experiencing dilemma with the stigma that society can not accept terrorist actors in society, he then believed that he should work hard to show that he is able to adjust again and deserve similar rights and obligations in society. His first dilemma allowed him to meet Ustadz Zakariya, a new head of Pesantren al-Islam, Lamongan. Yusuf explained that the Pesantren Al-Islam is now different from the old one, which was attached to the mass mobilization of jihad. In 2009, Ustadz Zakariya also asked Yusuf to meet Noor Huda Ismail, who eventually made Yusuf his employee in the food stalls. Yusuf then tried to be independent after securing investment from Noor Huda Ismail for IDR 50,000,000. Later, Noor Huda added his investment to IDR 30.000 .000 , made it IDR $80,000,000$ in total. This capital is used by Yusuf to open a restaurant named "Dapoer Steak" and "Dapoer Bakery" developed in Semarang and Solo. For now, Yusuf admitted that his thought of jihad is to put forward the concept of difä' jihad (defense, to survive), arguing that "if Muslims in their lands were attacked, he would strike (reply) back", using both conventional or guerrilla war.

Another interesting change of Yusuf was his thought about the concept of shari'a establishment. According to Yusuf, the enforcement of Islamic law does not necessarily need the establishment of an Islamic state. This seems contrary to his old understanding and activities as people who did qitāl jihâd in the name of religion and anti-secularism. According to Yusuf, his community in the past employed the concept of wasilah (intermediary or intercession), but this time the community has been fragmented, divided and separated between Muslims and non-Muslims, making it impossible to fully enforce sharia law. According to Yusuf, the most possible achievement at the present time is to acquire special autonomy. This thought gained by Yusuf when he was still in prison. 
For Yusuf, he materialized difä' jihad by da'wa, making money like opening a restaurant hence he could help his friends in prison. He said:

"The establishment of Islam can only be achieved through difä' jihad and da'wa. Jihad however likely turns its notion, where taking care of any economic community, fighting drugs. Within jihad and da'wa, there are two things, words and behavior, that must run equally. It means that we have to demonstrate not just through speaking, but also through tangible evidence such as the Islamic way of doing business so that the behavior of jihad must also adjust to the local culture. For example, since living in Semarang which is very close to Javanese culture, therefore it will not appropriate to preach violent use, instead, to use good manners are an obligation."

\section{Second Case: Abd $^{30}$}

Abd (initial name) is a native of Solo who during high school spent in Madrasah Aliyah Al-Mukmin Ngruki, where he was inspired by the concepts of politics as understood by the teacher Abdul Halim Abdullah Sungkar, one of the chairmen of the Al-Mu'min Foundation, Ngruki. However, Abd explained that in general, the lesson he received was similar standard to other Pesantren such as fiqh, naḥwu, șaraf, imlä' and so forth.

Abd moved to Malaysia, following his teacher, Abdullah Sungkar, who moved while waiting for the decision of the Indonesian Supreme Court regarding the subversive case in the 1985's. In Malaysia, Abd deepened the concepts of Islamic teachings such as jihad. Believing in God's guidance, Abd was grateful to get guidance from God that he was given the opportunity to conduct jihad in Afghanistan in 1988/1989and Ambon around 1999-2000.

Abd's departure to Afghanistan was supplied by the concept that "jihad is to help to relinquish injustice and infidelity". There is no jihad where there is no infidelity and persecuted Muslims, as clearly stated in the verse of Qur'an, said Abd.

The Sungkar's teaching on Indonesia categorized as not a Muslim country, although not all of its aspects, was one of the concepts that Abd approved. For Abd, in Indonesia, much Islamic law has not been enforced/implemented. Besides, he believed that the phenomenon of oil explained a lot toward the

\footnotetext{
30Abd, interview, July 15, 2012.
} 
government oppression against many Muslims, and therefore he chose da'wa which unfortunately the govt considered him a subversive actor.

In addition to the concepts taught his teacher, he also read many Abdullah Azzam's books circulated freely in Malaysia. Jihad as war is a political problem, needed to dialogue and determine its rank and its maqāșid problems. When it is obvious that its maqāsid is to combat infidelity and oppression, then take jihad to action.

Abd explained his opinion at the time that, Indonesia used law incompatible with Islam because of Pancasila is considered as the sole basis. Whereas Pancasila only as a symbol, as well as "al-Baqarah" is just a metaphor, therefore should not become the only one. Rejecting Pancasila as the national ideology and arguing that the foundations of the State are to be the rule of Allah in the Qur'an, Abd was then detained on subversion charges from 2002 to 2008 (about 7 years).

For Abd, only God who is able to inspire someone to do jihad, and he added that the law of jihad consists of two kinds, namely fardu 'ain (obliged for all Muslim) and fardu kifāyah (obliged only for some, or optional obligatory). If Ambonese still has the ability, the obligation of jihad for people who are not in Ambon is fardu kifāyah. However, if Ambonese Muslims are weak then the obligation of Muslims outside becomes fardu 'ain.

Abd admitted his understanding of jihad has never changed. He understands that jihad has global significance. Actually, in the Qur'an, there are two (2) meanings of jihad, fillāh and fi sabìlillāh. Fillāh is a jihad in the matter of education, organization, looking for treasure, and so forth, where jihad $f i$ sabilillāh must necessarily be qitāl. According to Abd, the jihad has many phases, insisting that "we cannot do the greater jihad (fi sabilillāh) before completing the lesser one, jihad fillāh".

In reality, jihad fi sabilillāh to those who were in Indonesia must meet the following requirements: 1) there must be a field of war, such as Palestine, 2) jihadist must have knowledge and fees, such as storing treasures, able to meet the needs of shopping for the family, and so on, so that families left behind should not be ignored. 3) It must be complex and ordered as well as follow the Sunnah. However, there are exceptions for people who God opens their heart for jihad and those people in the area that is oppressive and tyranny, then it is 
farḍu 'ain for jihad fi sabīlillāh as the provisions of the shari'a "infirū wa jāhidū anfusakum wa amwālakum fi sabilillāh." Abdullah also explained that in fact when he joined the jihad to Ambon, it was fard kifāyah since at that time he was in Malaysia, which is in a different area. And the best thing for people when they did not come to Ambon is by providing supplication. However, jihad to Ambon is the most primary one among many another states of jihad such as praying.

Now, the most possible jihad for conditions such as Semarang is jihad $b i$ ' $l$ lisān (words), by preaching, writing and so forth, said Abd. However, he might be back in the jihad of war when there is oppression against Muslims. Although it necessarily needs to consider and take a lesson from his last jihad.

In addition to jihad by the words, he also wanted to establish a partnership in understanding religious teachings and finding a solution for jihadists friends, as well as sharing knowledge as he did with Noor Huda Ismail. For Abd, the legal issues can change, either mandatory or not necessarily required for some time, implying that muhāsabah (correction or consideration) is very important. In the context of Indonesia, Abdullah concluded that qitäl is only relevant when Muslims are oppressed. If they cannot do qitāl, then praying is also one of the jihad.

\section{Third case: $\mathbf{H} \mathbf{r}^{31}$}

$\mathrm{Hr}$, an initial name, graduated from high school in 2000. Starting religious activity since the year of 1993/1994, Hr admitted that he liked to join some organizations, gave attention to social issues and joined religious studies. Participating Red Cross Youth (PMR)/Indonesian Red Cross (PMI) since junior high, $\mathrm{Hr}$ also tried many other activities which did not impress him and eventually he joined Rohis (Rohani Islam) at his high school.

According to $\mathrm{Hr}$, there was actually no fundamentalist view received from his friends who did jihad. Rather he gained religious knowledge from the senior brothers in Rohis through the discussion and actively engaged to the forum of Rohis' chairmen.

\footnotetext{
31Hr, interview, June 18, 2012.
} 
$\mathrm{Hr}$ then explained the phases of his understanding and behavior that he passed. According to him, in 1995, he got only a motivational knowledge; which incidentally fitted the conditions in Indonesia, where many religious conflicts still did not emerge.

At that time, his involvement in religious activity was not intense enough, since his father died when $\mathrm{Hr}$ was in the third grade of high school. Expected to be financially independent, he just followed just on few occasion. According to $\mathrm{Hr}$, neither did he know the teaching was radical, clearly it played as motivation, a first stage he considered to be jihad since he thought that jihad was only a small part of Islamic teaching.

When studying at Diponegoro University, Hr often learned to Budi, a senior in Rohis. Among the teachings of Rohis he received was "the government should be based on the legally and formally caliphate, as long as there is no caliphate-based government, it is considered un-Islamic". Some ustadh taught that the government in Indonesia at that time fell into this category, which has no caliphate on its ground.

Other teachings he received from the side of 'aqìdah is that someone should be based on the teachings of 'aqìdah core of "lā iläha illa Allāh and lā hukma illā Illāh" (no law except the law of Allah), then such beliefs should be drawn to the existing problems in the country this. Therefore, the way to create an Islamic Caliphate can only be done through a war based on the prophet's stories and the past apostolic. Actually, jihad is a war, the only great jihad. Therefore, there is jihad against lust, jihad is just equal to qitāl.

$\mathrm{Hr}$ deeply admitted that to deliver their teaching, his teachers used the deductive method, where a theory put before reality. However, the application is still problematic and open to question. Hr exemplifies the teachings that he received from his teacher Ustad Subur like "When you meet the unbelievers, kill where you find" is, for Hr, just a theory, in reality, he does not think so. According to him, if the infidels include a hypocrite, then when there are three characteristics of hypocrites, he perhaps belonged to those people in that category, something he considered it as illogical. Thus, conceptually he agrees with these teachings, but in the level of applications, he still disagrees.

$\mathrm{Hr}$ said that his actual reason to enter an organization is ABS (Asal Bapak Senang/just to make a father happy) or ATS (Asal Ustad Senang/just to make 
the teacher happy). However, he had principles that before holding the authority of an organization, he must comprehend its concept first. For example, he said that he joined the Partai Keadilan (Justice Party) in 1999, but in 2000 he resigned because when converted into the Prosperous Justice Party (PKS), it has been turned from its original destination.

Furthermore, $\mathrm{Hr}$ revealed that one of the factors preventing him for jihad (qitāl) is for the family. In 2002, he married so that the needs of his families rose and he must fulfill it. He has never participated in a practical jihad movement. He explained that he still did "local jihad". When offered to do jihad, he had never wanted to, because he was still unsure about the application. Even in 2005 when a friend asked "Hr, have you been ready?" Hr replied: "for what?" His friend replied: "Ready for jihad. Are you ready (to do jihad) in "ngarep" (front), "tengah" (middle) or "mburi" (back)?" His friend implied that "ngarep" means himself personally, "tengah" means his family and "mburi" means his family's supporting economy. Hr did not accept immediately since he has a plan for himself, his family and his mother.

$\mathrm{Hr}$ argued that qitāl jihad was farḍu kifāyah for him, unlike his friends who make jihad as fardu 'ain, like prayer. According to Hr, the closest fardu 'ain is to Ambonese Muslims since problems in Ambon led to SARA (Ethnic, Religion, Race, and Intergroup).

In 2005, $\mathrm{Hr}$ was arrested after his teacher, Ustad Subur, an accomplice of Nurdin M. Top, was caught and Hr himself was considered to conceal Ustad Subur. Hr explained that when asked to mention the name of his students by police, Ustad Subur mentioned his name. Finally, $\mathrm{Hr}$ was charged to hide his teacher based on article 13 letter bc Criminal Code, "When someone knows a convicted one and do not report it, it is considered to conceal"and got penalized for 5 years confinement.

In Semarang context, according to $\mathrm{Hr}$, there are two movements of "jihad", are structured and unstructured jihad. Structured jihad is a congregation (DI, TII, Jama'ah Islamiyah), while the unstructured is like Nurdin M. Top. Admitting that he was part of unstructured/disorganized one, $\mathrm{Hr}$ himself claimed that Nurdin was aided by a structured organization, for the reason of empathy and similar aspiration in their hearts. For example, Nurdin often 
asked Ustad Subur to provide " bride of a bomb", and Ustad Subur then persuaded his students including $\mathrm{Hr}$, in which $\mathrm{Hr}$ always said he was not ready so he was unable to do jihad.

The concept of jihad guided by Ustad Subur itself is Abdullah Azzam's concept as can be seen from his books. Hr even admitted that he also accepted some of the jihad teachings of Abdullah Azam translated into Indonesian, even though it was taken all as evidenced by the police during the investigation.

Since the beginning until now, $\mathrm{Hr}$ explained that his understanding of jihad is still the same. Conceptually he will not switch from the original concept of jihad, however, he disagrees and argues that such jihad is difficult to implement. Hr likened jihad as the roof of a house, where there are cornerstones, pillars, easels, and then the roof. The cornerstone is the Islamic Aqidah, the pillar is sharia, while the roof or patron is jihad. The same is government, where its roof is the police and the military. The most suitable jihad likened to the roof is a defensive jihâd/survival, insisting that people should do jihad when Muslims are persecuted based on its solid foundation.

For recent Indonesian context, $\mathrm{Hr}$ explained that the understanding of jihad must not be qitāl, implying that if you want qitāl, you should go to Palestine of which being occupied by the Israelis or when the Dutch colonized Indonesia at that time. Qitāl happened when the two armies face to face, thus the Bali bombing either first or second is nothing jihad but a sporadic act.

$\mathrm{Hr}$ admitted that his understanding of the reasons and where to do jihad qitāl was different from his teacher, Ustad Subur who said that qitāl should be done wherever they are. For $\mathrm{Hr}$, jihad becomes fardu 'ain for local people where Islam is attacked. There was no need for the people of Indonesia to be invited to Palestine since it was a fardu kifäyah. What is fardu 'ain for $\mathrm{Hr}$ is to make a living for his family, a constant understanding of jihad until 2009, where he was out of prison.

While living in prison, $\mathrm{Hr}$ met Noor Huda Ismail and friends who voluntarily helped to think of how he would be accepted by the community and able to live a life within. However, his relationship with Huda did not change his position and views on jihad. For Hr, many positive things he obtained from his friendship with Huda, including: 1) knowledge; 2) expanding the relationship, and 3) the nice concept of donations. The concept he approves 
of Huda, he said, was how to raise their brothers in jail to be independent and organized. Hr realized that in jail, jihadist militants separated themselves, while the middle (neutral) person who knows nothing mingle with another prisoner. $\mathrm{Hr}$ also admitted he was not a militant, especially after Huda approached him and helped him money to manage his fishpond in 2011-2012.

\section{Changing Orientation of Jihad and Its Strategy to Handle}

As Weber ${ }^{32}$ and Hanafi ${ }^{33}$ argue, religion as a worldview is not only at the level of ideology but also gives directions for the ideal acts for the believer, reflecting that what is believed to be a religious ideology of jihād fi sabilillāh should be more internalized in a religious movement. Qitāl movement committed by jihadists in Semarang is one of the diverse realities departing from a subjective understanding of the sacred religion evoked by their teachers and the people who motivated them ${ }^{34}$ hence the spirit of the movement is carried out to support its sacred.

It is reflected on Yusufs understanding of "Lā ḥukma illā lillāh" and "al mu'minu al-qawiyyu aḥabbu 'inda Allāh", also the verse of "... faqtulü haythu wajadtumūhum" and " faqtulū haythu thaqiftumūhum". Similarly, it is also portrayed on Abdullah who adheres qitāl virtues of jihad to fight against those considered infidels or those following the infidels. Their understandings and acts of jihad in past is certainly very different from Rumadi explanation that jihad as a form of religious sanctity is opposite when implemented with qitāl.35 Rohimin added that jihad contained in the Qur'an is jihad in the Qur'an (aljihād bi 'l-Qur'ān), jihad with wealth (al-jihād bi 'l-māl), and jihad with soul (aljihād bi 'l-nafs). ${ }^{36}$ Fazlur Rahman concluded it, saying that jihad is a total effort made by Muslims, not only qitāl.37

Of Yusuf and Abd cases, it is revealed their teachers play an important role towards their understanding of jihad, in addition to other supporting factors

\footnotetext{
32Schroeder, Hegemoni Sistem Kepercayaan, 83.

${ }^{33}$ Hanafi, Islam in the Modern World, 410.

${ }^{34}$ Giddens, Kapitalis dan Teori Sosial Modern.

35Rumadi, Renungan Santri, 83.

36Rohimin, Jihad, 10.

37Rahman, Tema Pokok Al-Qur'an, 93-94.
} 
such as Yusuf s experience on the existential and economic needs and Abd's experience on socio-political life. It is very different however from Hr's experience on economic and family factors that influence his behavior of jihad in addition to, according to him, the theory of jihad which is difficult to implement. It makes Hr's choice from the beginning more inclined to perform difä'jihad, although he still mingled with jihadists of qitāl. Thus it is true that, as Arkoun has theorized, ${ }^{38}$ the attraction between the political and social factors have created the ideological form in the human mind.

From the perspective of understanding jihad, those three jihadists have the same opinion, because the reference used is also the same, such as Abdullah Azzam's essays and others. It means that in addition to the factors of their teachers, the books they read also greatly affect their understanding of jihad.

During their imprisonment, as they acknowledged, Government delivered some de-radicalization programs to change their understandings of religious teachings, social and other issues. Yusuf arguing, however, admitted that there are important people who successfully changed their orientation towards jihad, shifting them from qitāl to difä'. For instance, he recognized his meeting with Noor Huda Ismail provided him some insight into the importance of changing the orientation of jihad by doing more on empowering communities, helping brothers living in jail and even giving the share capital for their businesses. Their concept of jihad still remains but alters toward its behavior in the sense that difä' jihad becomes more mainstream. Difä' in this case is done by strengthening the economic side of jihadists who still live inside or outside the jail by giving, caring and helping them to survive within society.

It underlines one important strategy that someone who wants to change jihadists' orientation, according to Huda, must be able to humanize a human, to understand that those who do jihad are good people who want to live Islam totally (käffah) and has emotional closeness. ${ }^{39}$ Yusuf confirmed it, saying that Huda was, in the past, one the students of Al-Mukmin Ngruki, a place where they accepted and shared a similar understanding on jihad from their teachers. That exactly confirms what Huda did, empowering those jihadists using an emotional, social and economic approach or as Huda simply calls it an effort to

${ }^{38}$ Arkoun and Lee, Rethinking Islam.

${ }^{39}$ Noor Huda, interview, June15, 2012. 
humanize a human and avoid accusing accuse them criminals but understand them as merely an effort to live Islam as a whole.

In addition, other strategies to do is "bridging without prejudice", 40 so that they feel safe and comfortable when returning to their community later. The government must employ this strategy, according to Huda, to address postconflict people. ${ }^{41}$

To repeating qitāl in the future, the jihadists furthermore answered that it is possible if there is a call for the jihad and fulfills its requirements, said Abdullah. Meanwhile, after reflecting and learning his jihad's experience that ended up on jail, Yusuf insisted that the possibility to return should be based on such a strong argument. Abdullah himself similarly explained that he could return to qitāl movement if there is persecution against Muslims, although he needs to deeply consider and learn from his past.

\section{Conclusion}

In the name of jihad, one's understanding of jihad deeply affects one's act. Normatively, they feel obliged to do jihad when someone experiences persecution against another Muslims and they are able to wage a war against the persecutors. However, it needs only to perform jihad difä' since they live in peace condition. To some extent, furthermore, the motives of performing jihad emerge also from other issues such as the genealogy of knowledge, the experience of diversity, the problems of seeking existence, economy, social and culture.

Some also affect the way they perform jihad, especially about their changing, from qitāl to difä'. First is the way of interaction. When the jihadists interact with other people who have the similar genealogy of knowledge, they will psychologically be easier to accept the concepts offered. Second is a humanistic method. It is more effective to change the jihadists since this method sees and treats them merely as a human and therefore is able to diminish prejudice. The third is an effective program. It offers and facilitates

\footnotetext{
${ }^{40}$ Huda's institution, Yayasan Prasasti Perdamaian, uses this motto as a way to rehabilitate and reassimilate post conflict people into society.

41Huda, interview, June15, 2012.
} 
the basic need of jihadists' life such as economic needs, self and social existence, for instance, by helping their comrades who still live in the jail.

Therefore, the government needs to build strategies and programs, which effectively restore the jihadists' existence in order to tackle the problem of jihadists in Indonesia. It is a must also to include their families in the programs since they also experience negative stigma after one or some of their family members involved in performing jihad.[a]

\section{BIBLIOGRAPHY}

Abd. “Interview." July 15, 2012.

Abidin, Ibn. Radd al-Mukhtār. Beirut: Dār al-Ma'ārif, 2003.

Ahyar, Muzayyin. "Membaca Gerakan Islam Radikal dan Deradikalisasi Gerakan Islam." Walisongo: Jurnal Penelitian Sosial Keagamaan 23, no. 1 (2015): 1-26. https://doi.org/10.21580/WS.23.1.220.

Ali, Atabik, and Ahmad Zuhdi Muhdlor. Kamus Kontemporer Arab Indonesia. Yogyakarta: Multi Karya Grafika, 1999.

Arkoun, Mohammed, and Robert D. Lee. Rethinking Islam: Common Questions, Uncommon Answers. Edited by Robert D. Lee. Michigan: Westview Press, 1994.

Bonner, Michael. Jihad In Islamic History: Doctrine and Practice. UK: Princeton University Press, 2008.

al-Bukhārī, Abū Abdullāh Muhammad bin Ismāîl bin Ibrāhim bin al-Mughīrah bin Barzdabah. Șahịh al-Bukhārī. Beirut: Dār al-Fikr, 1401.

Burhanudin, Asep. Ghulam Ahmad: Jihad Tanpa Kekerasan. Yogyakarta: LKiS, 2005.

Giddens, Anthony. Kapitalis dan Teori Sosial Modern. Jakarta: UI Press, 1986.

Hanafi, Hassan. Islam in the Modern World; Tradition, Revolution and Culture. 2nd ed. Cairo: Dar Kebaa Bookshop, 2000.

Hasani, Ismail, and Bonar Tigor Naipospos. Dari Radikalisme Menuju Terorisme. Jakarta: Pustaka Masyarakat Setara, 2012.

Hilmy, Masdar. Islam Profetik: Substansi Nilai-nilai Agama dalam Ruang Publik. Yogyakarta: Kanisius, 2008.

Hr. "Interview.” June 18, 2012. 
Huda, Noor. “Interview.” June15, 2012.

Katz, Samuel M. Jihad: Islamic Fundamentalist Terrorism. Minneapolis: Lerner Publications Company, 2004.

Kepel, Gilles. Jihad: The Trail of Political Islam. London, UK: I.B.Tauris, 2002.

Khadduri, Majid. War \& Peace in the Law of Islam: Perang dan Damai \& Hukum Islam. Edited by Kuswanto. Yogyakarta: Tarawang Press, 2002.

Kusmanto, Thohir Yuli, Moh. Fauzi, and M. Mukhsin Jamil. "Dialektika Radikalisme dan Anti Radikalisme di Pesantren." Walisongo: Jurnal Penelitian Sosial Keagamaan 23, no. 1 (2015): 27-50. https://doi.org/ 10.21580/WS.23.1.221.

Lukens-Bull, Ronald Alan. Jihad Ala Pesantren di Mata Antropolog Amerika. Edited by Abdurahman Ma'ud. Yogyakarta: Gama Media, 2004.

Miswari, Zuhairi. "Islam dan Terorisme." Islam Lib, 2002. http://islamlib.com/ politik/radikalisme/islam-dan-terorisme/.

Mulkhan, Abdul Munir. Manusia Al-Qur'an: Jalan Ketiga Religiousitas di Indonesia. Yogyakarta: Kanisius, 2007.

Poerwadarminta, W.J.S. Kamus Umum Bahasa Indonesia. 3rd ed. Jakarta: Balai Pustaka, 2006.

Qardhawi, Yusuf. Fiqh Jihad: Sebuah Karya Monumental Terlengkap tentang Jihad Menurut Al-Qur'an. Bandung: Mizan Publika, 2010.

Rahman, Fazlur. Tema Pokok Al-Qur'an. Bandung: Pustaka, 1983.

Rohimin. Jihad: Makna dan Hikmah. Jakarta: Erlangga, 2007.

Rumadi. Renungan Santri; Dari Jihad Hingga Kritik Wacana Agama. Jakarta: Erlangga, 2006.

Schroeder, Ralph. Max Weber tentang Hegemoni System Kepercayaan. Edited by Ratna Noviani. Yogyakarta: Kanisius, 2002.

Sulasman, Sulasman. "Peaceful Jihād dan Pendidikan Deradikalisasi Agama." Walisongo: Jurnal Penelitian Sosial Keagamaan 23, no. 1 (2015): 151-76. https://doi.org/10.21580/WS.23.1.228.

Tim Redaksi Kamus Besar Bahasa Indonesia. Kamus Besar Bahasa Indonesia. 3rd ed. Jakarta: Balai Pustaka, 2005.

Warson, Ahmad. Kamus Arab-Indonesia Al-Munawir. Surabaya: Pustaka Progressif, 1997.

Yusuf. “Interview." June 12, 2012. 
